Manuela Ingaldi ${ }^{1}$

\title{
EVALUATION OF SERVICE QUALITY IN THE BREWERY WITH USE OF THE SERVPERF
}

\begin{abstract}
Service quality, because of their specificity, it is difficult to assess, especially since there is no its materiality her, it can't be seen. In such quality analysis special types of methods are used, among which the Servqual method and its variation the Servperf method should be mentioned. In the article the Servperf method was used to evaluate the quality of services in the chosen brewery. In this method the customer does not evaluate his expectations for the service, but only the final service. The aim of the chapter was to evaluate the quality of services offered by chose brewery in Czestochowa and to show superiority method Servperf over by Servqual method.
\end{abstract}

Key words: quality, service, restaurant, Servperf

\section{Introduction}

Beer is the oldest and most widely consumed alcohol in the world (ARNOLD J.P. 2005). Brewing tradition on Polish territory date back to ancient times, history of the Slavic peoples and the beginnings of the Polish state. The beer is the most popular alcoholic beverage among the Slavs (LIS A., LIS P.2009). Poland is the fourth in the world in terms of beer consumption per capita (FAŁat Z., GórSKA R., Plinta P., SADOWNIK A., WOJTALA D. 2002). Especially small, local breweries, offering unique types of beers, are very popular lately. Polish people like to meet in a pub or restaurant with beer and snacks.

This how the customer feels in a particular place, and how has been served, influences his decision if to return to such place. Therefore, to verify that the catering services in a particular place is popular, the quality of the services offered by such place should be conducted.

${ }^{1}$ Dr inż., Politechnika Częstochowska, Wydział Zarządzania, Instytut Inżynierii Produkcji, e-mail: manuela@gazeta.pl 
One of the most used tool of the service quality analysis is the Servqual method (Service Quality). It is used by many different companies, first of all by such as hotels, banks, hospitals, shops. It was created by Berry, Parasuraman and Zeithaml (KonstANCIAK M. 2012); (INGALDI M., JURSOVA S. 2013). The Servqual method uses a multi scale, by means of which it is possible to measure of the service quality from the point of view of customer, to get many hints associated with the directions of the quality improvement. This method treats quality as the difference between customer expectations and actual perceptions of the service. The analysis of the service quality by the Servqual method begins with selection of the appropriate set of service quality determinants (KADŁUBEK M. 2011).

The Servperf method (Service Performance) is less known, however, an interesting method of the service quality analysis. It was created as a contrast proposal to the Servqual method. The basic assumption the Servperf method is to improve the service quality. It was created by Cronin and Taylor, who found out that we cannot examine customer expectations, because the expectations belong to the ambiguous and variable category. They can change very easily. The Servperf method, unlike the method Servqual, examines only the level of quality of the received, realized service (perception), and compares it to the ideal services (STOMA, 2012). This method gets rid of the subjectivity, because the customer does not specify in advance its often unreasonable expectations about the service. The general formula of the method is very easy, which from a practical point of view makes it easier to apply. The service quality is compared to customer perception (KUCIŃSKA A. 2007); (KUCIŃSKA A., KoŁOSOWSKI M. 2009). This method is therefore easier to use and less time-consuming compared to the Servqual method (GILMORE, 2003).

Evaluation and measurement of the quality service in the Servperf method is based on determinants derived from the Servqual method. Measurement of the service quality is made with a seven semantic rating scale (Likert scale), where the lowest level of the scale is: weak, and the 
best: excellent - so similar like in the Servqual method. The better service quality examined by this method is, the closer the individual scores to the maximum value is (GARCZARCZYK J. 2000).

The aim of the chapter was to evaluate the quality of services offered by chose brewery in Czestochowa and to show superiority method Servperf over by Servqual method.

\section{Methodology}

In the research presented in the chapter 137 customers of chosen brewery took part. The research had a form of the Internet survey about which fulfilment were asked customers after using the services offered by the research company. Electronic form of the survey provides greater anonymity and facilitates data collection and sorting of results.

The proper preparation of the survey is very important element of the research. It should be remembered that the survey must be written in simple language that everyone can easily understand, and questions should not be too long, not be boring for the respondent. Appropriate questions must also provide as much information about the quality of the test service as possible (LESTYÁNSZKA ŠKŮRKOVÁ K., INGALDI M. 2014); (DZIUBA S.T., SZOŁTYSEK K., KOZYRA C. 2011).

In Table 1 all determinants, which were evaluated during the research, divided into five basic groups, were presented. In Table 2 the original part of the original survey about empathy of the staff with its determinants were shown. The customers were supposed to evaluate every determinant according to the Liker's scale presented in this Table. Table 3 includes weights of all individual groups of determinants (also part of the original survey). The respondents had to divide 100 points between the individual groups. It can therefore be noted that the survey itself is very similar to the survey of the Servqual method, only the part concerning expectations for the service is omitted. 
Table 1. Statement in the survey Servperf

\begin{tabular}{|c|c|c|}
\hline No & Group & Statement (determinant) \\
\hline 1. & \multirow{7}{*}{ 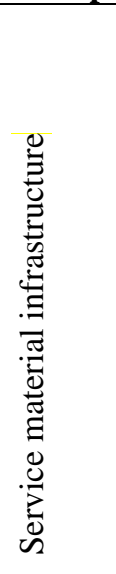 } & $\begin{array}{l}\text { The research brewery is conveniently located and has easy } \\
\text { access. }\end{array}$ \\
\hline 2. & & $\begin{array}{l}\text { Building of the research brewery is attractive, encourages } \\
\text { people to enter. }\end{array}$ \\
\hline 3. & & $\begin{array}{l}\text { Close to the research brewery there is a parking with an } \\
\text { appropriate amount of parking spaces. }\end{array}$ \\
\hline 4. & & $\begin{array}{l}\text { During spring-summer time the research brewery has a summer } \\
\text { garden. }\end{array}$ \\
\hline 5. & & $\begin{array}{l}\text { Interiors of the research brewery is attractive and well } \\
\text { equipped. }\end{array}$ \\
\hline 6. & & $\begin{array}{l}\text { The research brewery has attractive dishes that creates a unique } \\
\text { atmosphere. }\end{array}$ \\
\hline 7. & & $\begin{array}{l}\text { The research brewery has comfortable, clean toilets, also } \\
\text { adapted for disabled people and mothers with newborns. }\end{array}$ \\
\hline 8. & \multirow{3}{*}{ 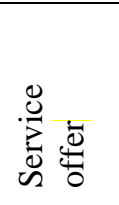 } & Offer of the research brewery is updated. \\
\hline 9. & & $\begin{array}{l}\text { Opening hours of the research brewery are convenient for } \\
\text { customers. }\end{array}$ \\
\hline 10. & & $\begin{array}{l}\text { The research brewery offers the possibility of organizing } \\
\text { individual events. }\end{array}$ \\
\hline 11. & \multirow{5}{*}{ 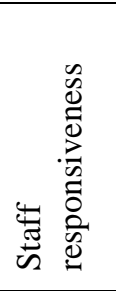 } & Staff of the research brewery looks neat. \\
\hline 12. & & $\begin{array}{l}\text { Staff of the research has adequate knowledge about the offered } \\
\text { services. }\end{array}$ \\
\hline 13. & & Staff of the research brewery is polite. \\
\hline 14. & & $\begin{array}{l}\text { Staff of the research brewery responds quickly to customer } \\
\text { requests. }\end{array}$ \\
\hline 15. & & Staff of the research brewery fast brings customer orders. \\
\hline 16. & \multirow{3}{*}{ 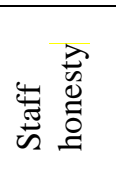 } & In the research brewery service always complies with the order. \\
\hline 17. & & In the research brewery a bill always complies with the order. \\
\hline 18. & & $\begin{array}{l}\text { Staff of the research brewery always provides customers with } \\
\text { help. }\end{array}$ \\
\hline 19. & \multirow{3}{*}{ 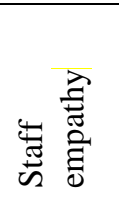 } & $\begin{array}{l}\text { Staff of the research brewery devotes much attention to } \\
\text { customers. }\end{array}$ \\
\hline 20. & & $\begin{array}{l}\text { Staff of the research brewery understands the specific needs of } \\
\text { customers. }\end{array}$ \\
\hline 21. & & Staff of the research brewery is communicative. \\
\hline
\end{tabular}

Source: own study 
Table 2. Evaluation of chosen group of determinants - part of the original

\begin{tabular}{|c|c|c|c|c|c|c|c|c|}
\hline \multicolumn{9}{|c|}{ survey } \\
\hline & \multirow[t]{2}{*}{ Statement (determinant) } & \multicolumn{7}{|c|}{$\begin{array}{l}\text { Evaluation according to Liker's } \\
\text { scale }\end{array}$} \\
\hline & & 1 & 2 & 3 & 4 & 5 & 6 & 7 \\
\hline \multirow{3}{*}{ 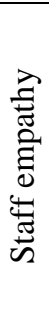 } & $\begin{array}{l}\text { Staff of the research brewery } \\
\text { devotes much attention to } \\
\text { customers. }\end{array}$ & & & & & & & \\
\hline & $\begin{array}{l}\text { Staff of the research brewery } \\
\text { understands the specific needs of } \\
\text { customers. }\end{array}$ & & & & & & & \\
\hline & $\begin{array}{l}\text { Staff of the research brewery is } \\
\text { communicative. }\end{array}$ & & & & & & & \\
\hline
\end{tabular}

Source: own study

Table 3. Weight of individual groups of determinants - part of the original

\begin{tabular}{|l|l|}
\hline \multicolumn{2}{|c|}{ survey } \\
\hline Group of determinants & Number of points \\
\hline Service material infrastructure & \\
\hline Service offer & \\
\hline Staff responsiveness & \\
\hline Staff honesty & \\
\hline Staff empathy & \\
\hline
\end{tabular}

Source: own study

In case of each individual determinant, the average evaluation was calculated. Only these results were presented in the graphical way. Different type of graphic forms were used. At the beginning with use of the histogram average values for each determinant were presented, to identify those that got the highest evaluations. Then with use of the same kind of graphic the comparison of the average value of individual determinant was compared to ideal evaluation (percentage fraction to evaluation 7). Then with use of the reversed histograms wages and average values for each group of determinants were presented. The arithmetic average and the weighted average for all determinants were calculated and then they were compared to ideal evaluation. For the 
calculation of the weighted average, weights of the individual groups of determinants were used.

\section{Characteristics of the research object}

The research brewing company is a unique brewery. It is located in Czestochowa and is the only active brewery in this area. The beer is produced in front of the guests, guaranteeing a unique atmosphere and builds a unique climate.

At the end of the XX century economic changes caused that in place of the brewery a warehouse appeared. At that time, the building began to fall, to the point where at the beginning of the XXI century the Brewery and Restaurant appeared. The brewery is able to produce approximately 500 hectolitres of beer per year. For a beer production, only malt, yeast, hops and water of high quality are used. Brewing is performed using the craft method in accordance with good brewing traditions. Apart from the pleasure to drink beer in this place, the catering services, special events, concerts, people can take the beer home in a specially prepared bottles with the logo of the brewery.

\section{Results}

In Figure 1 the average values of evaluations given by respondents to individual determinants were presented. While in Figure 2 these value were compared to the ideal evaluation (evaluation in Liker's scale). 


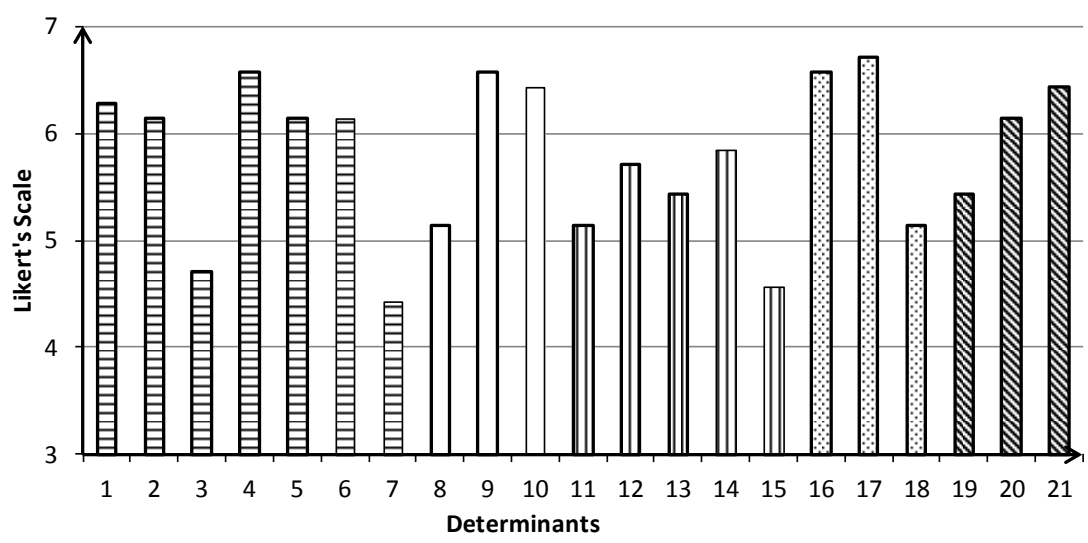

Fig. 1. Aggregated results for the Servperf method. Source: own study

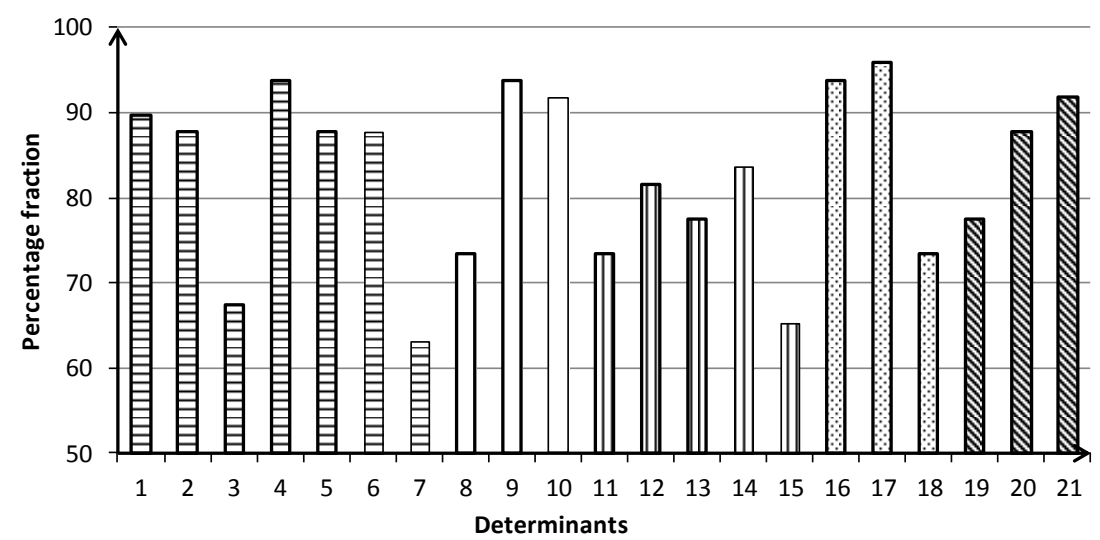

Fig. 2. Percentage in relation to the Likert's scale for the Servperf method. Source: own study

From Figures 1 and 2 it can be concluded that respondents, evaluating the quality of services in the research brewery, gave the highest evaluation to the statement 17 e.g. in the research brewery a bill 
always complies with the order. It mean that they can see that employees of the brewery are honest and don't try to cheat if it comes to money.

Other highly evaluated statements are statements: 4 i.e. during spring-summer time the research brewery has a summer garden; 9 i.e. opening hours of the research brewery are convenient for customers; 16 i.e. in the research brewery service always complies with the order; 10 i.e. the research brewery offers the possibility of organizing individual events; 21 i.e. staff of the research brewery is communicative.

For people who go to such place with the whole family, especially children, the summer garden is a big convenience, and often a decisive factor about the place, as well as opening hours. Customers always want to get what they ordered, do not like when the waiters make mistakes, because evaluation of the statement concerning orders is very important. Such places like the brewery is an interesting place to organize events that bring high returns to the company, and therefore high evaluation of this statement. A very big plus for employees who are communicative, and thus know how to get along with often grumpy customers.

Customers evaluated the worst statement 7 i.e. The research brewery has comfortable, clean toilets, also adapted for disabled people and mothers with newborns. The brewery is a place where very small children are not taken due to the atmosphere.

Other low evaluated statements are statements: 15 i.e. staff of the research brewery fast brings customer orders; 3 i.e. close to the research brewery there is a parking with an appropriate amount of parking spaces. When going with family, friends, colleagues there to spend free time, people do not want too quickly leave this place, so do not care about the quick service in real. What is more, in the brewery frequently ordered drink is beer, and therefore rarely people go there by car.

In Figure 3 weights of each group of determinant given by respondent were presented while in Figure 4 average values of each group were shown. 


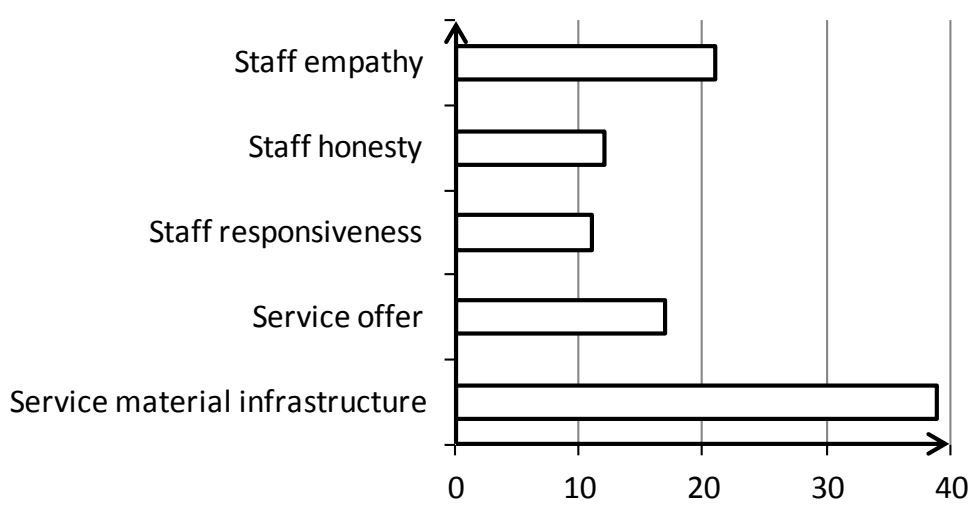

Weights of individual group of determinants

Fig. 3. Weights of individual group of determinants.

Source: own study

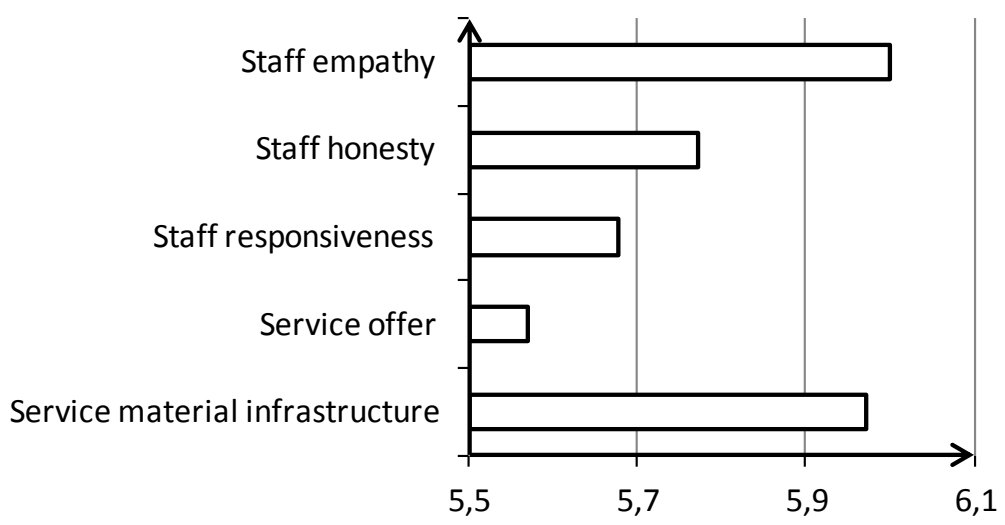

Average values of individual group of determinants

Fig. 4 Average values of individual group of determinants.

Source: own study

From the conducted analysis (Figure 3 ) it results that the customers most frequently pointed to the service material infrastructure (average 39 
points out of 100). It should be remembered that by going to the brewery at the beginning people look at the design, furniture, menu. These are the elements that often decide on its final evaluation. First impression always stays.

In case of the research brewery the determinants of staff empathy got the highest average evaluation, on the second place service material infrastructure (Figure 4). Oznacza to, że zarówno zachowanie pracowników, jak i wystrój browaru podobały się klientowi.

The total average value for all determinants was also calculated. This calculation was made in two different ways: as an arithmetic average XA and as weighted average XW.

$$
\begin{aligned}
X A & =5.80 \\
X W & =5.85
\end{aligned}
$$

On average, determinants were evaluated at 5.80, after taking into account weights the average was 5.85 (it was slightly lower than the arithmetic average). It means that the determinants were evaluated at a quite high level (over 5 points). Referring both averages to ideal evaluation, it was $82.86 \%$ and $83.57 \%$. It means that the services offered by the research brewery on average approx. $83 \%$ meet customer expectations.

\section{Summary}

The service quality analysis is very important due to the development of the service sector in the Polish and world economy, and also because of the difficulty associated with the fact that services have non-material form and it is often difficult to tell what really is evaluated. The service quality and its analysis are completely different from the products quality. Therefore, to analyse the service quality separate research methods, such as Servqual, or its variant Servperf method were created.

In the article to evaluate service quality in the chosen transport company the Servperf method was chosen. It is less popular than the Servqual method, but according to the literature (STOMA M. 2012; 
GILMORE A. 2003) more objective due to the fact that the customer does not evaluate his expectations for the service, but only the final service, which may have an impact on the objective research result.

The conducted research let show that the customers, who decided for the services offered by the research brewery, on average estimated that these services in about $83 \%$ met their expectations. The determinants that had the highest positive impact on the results were determinants marked with numbers $17,4,9,16,10,21$. The determinants that had the lowest positive impact on the results were determinants marked with numbers 7 , 15, 3. These determinants should be taken into account by the management of the brewery in order to improve the quality of its services.

The research showed also that the customers pay much attention on service material infrastructure. This is a group of the determinants which can be seen, touch and it is easier to evaluate.

Brewery and restaurant market is a market where there is a lot of competition. A satisfied customer comes back to such place alone or with his friends, colleagues, so it's important to take care of the quality of the offered services.

In the chapter it was shown that the omission of the customers' expectations in the survey Servqual does not mean that the analysis is incomplete. What is more, it is possible to draw from it a lot of interesting conclusions and get rid of subjectivism of the expectations.

\section{Bibliography}

1. ARNOLD J.P. 2005. Origin and History of Beer and Brewing: From Prehistoric Times to the Beginning of Brewing Science and Technology. BeerBooks, Cleveland, Ohio.

2. Dziuba S.T., SzoŁtysek K., Kozyra C. 2011. Application of FAM - Fail Assessment Method - to optimization of unit costs of producing flours for . special purposes. [In:] Improvement of Production Process, Ed. Borkowski, S., Krynke, M. TRIPSOFT, Trnava. pp.28-39. 
3. Falat Z., Górska R., Plinta P., Sadownik A., Wojtala D. 2002. Przewodnik piwosza. Pascal, Bielsko-Biała.

4. GARCZARCZYK J. 2000. Jakość ustug bankowych i ubezpieczeniowych. Diagnoza, determinanty, segmentacja. Akademia Ekonomiczna, Poznań.

5. GILMORE A. 2003. Services Marketing and Management. Sage. London.

6. IngALdi M., JuRSOVA S. 2013. Wykorzystanie metody Servqual do badania satysfakcji klientów punktu obsługi indywidualnego klienta dystrybucji gazu. Rynek Energii, No 4, pp. 43-47.

7. KADŁUBEK M. 2011. Servqual jako metoda badania jakości obstugi $w$ logistyce. Logistyka, No 5, pp. 681-684.

8. KONSTANCIAK M. 2012. Wykorzystanie metody Servqual do analizy jakości ustug kurierskich logistyka. Logistyka, No 6, pp. 139-143.

9. KUCIŃSKA A. 2007. Ocena skuteczności SZJ jako narzędzie jego doskonalenia. Problemy Jakości, No 5, pp. 17-21.

10. KUCIŃSKA A., KoŁosowsKI M. 2009. Zastosowanie metody SERPERV do oceny zadowolenia klienta. [In:] Konferencja Innowacje w Zarządzaniu i Inżynierii Produkcji, Zakopane.

11. LESTYÁNSZKA ŠKŮRKOVÁ K., INGALDI M. 2014. Recycling process of the aluminium cans as an example of the renewable material sources. Advanced. Materials Research, Vol. 1001, pp 103-108.

12. LIS A., Lis P. 2009. Kuchnia Słowian. O żywności, potrawach i nie tylko.... Libron, Kraków.

13. Sтома M. 2012. Modele i metody pomiaru jakości ustug. Q\&R Polska Sp. z o.o. Lublin. 